\title{
Article \\ Effect of Interdendritic Precipitations on the Mechanical Properties of GBF or EMS Processed Al-Zn-Mg-Cu Alloys
}

\author{
Sangeun Park ${ }^{1}$, Saif Haider Kayani ${ }^{1}{ }^{\oplus}$, Hyungrae Kim ${ }^{2}$, Im Doo Jung ${ }^{3}$, N.S. Reddy ${ }^{1}$, Kwangjun Euh ${ }^{4,5}{ }^{\circledR}$, \\ Jae Bok Seol ${ }^{1}{ }^{\mathbb{D}}$, Jung Gi Kim ${ }^{1, *}$ and Hyokyung Sung ${ }^{1, *}$ \\ 1 Department of Materials Engineering and Convergence Technology, Gyeongsang National University, \\ Jinju 52828, Korea; sangeun21@gnu.ac.kr (S.P.); saifkayani@gnu.ac.kr (S.H.K.); nsreddy@gnu.ac.kr (N.S.R.); \\ jb.seol@gnu.ac.kr (J.B.S.) \\ 2 Korea Aerospace Industries, Sacheon 52529, Korea; grandfinal@naver.com \\ 3 Department of Mechanical Engineering, Ulsan National Institute of Science and Technology, \\ Ulsan 44919, Korea; idjung@unist.ac.kr \\ 4 Department of Aluminum, Korea Institute of Materials Science, Changwon 51508, Korea; keuh@kims.re.kr \\ 5 Advanced Materials Engineering, Korea University of Science and Technology (UST), Daejeon 34113, Korea \\ * Correspondence: junggi91@gnu.ac.kr (J.G.K.); hksung@gnu.ac.kr (H.S.)
}

check for

updates

Citation: Park, S.; Kayani, S.H.; Kim, H.; Jung, I.D.; Reddy, N.S.; Euh, K.;

Seol, J.B.; Kim, J.G.; Sung, H. Effect of Interdendritic Precipitations on the Mechanical Properties of GBF or EMS Processed Al-Zn-Mg-Cu Alloys. Crystals 2021, 11, 1162. https:// doi.org/10.3390/cryst11101162

Academic Editor: Bolv Xiao

Received: 31 August 2021

Accepted: 20 September 2021

Published: 24 September 2021

Publisher's Note: MDPI stays neutral with regard to jurisdictional claims in published maps and institutional affiliations.

Copyright: (c) 2021 by the authors. Licensee MDPI, Basel, Switzerland. This article is an open access article distributed under the terms and conditions of the Creative Commons Attribution (CC BY) license (https:/ / creativecommons.org/licenses/by/ $4.0 /)$.

\begin{abstract}
The effects of nanoprecipitations on the mechanical properties of Al-Zn-Mg-Cu alloys after GBF (gas bubbling filtration) and EMS (electromagnetic stirring) casting were investigated. Dendritic cell structures were formed after GBF processing, while globular dendritic structures were nucleated after EMS processing. Equiaxed cell sizes were smaller in the EMS-processed specimens compared to the GBF-processed specimens, confirmed by EBSD (electron backscatter diffraction) analysis. Nanoprecipitations of $\eta^{\prime}$ phases inside of dendrites were observed by TEM (transmission electron microscope), and other Fe-bearing compounds were located in the dendritic boundaries. The yield strength of the T4 and T6 heat-treated specimens was close to $400 \mathrm{MPa}$ and $500 \mathrm{MPa}$, respectively. Fractographic analysis was performed to investigate the effect of precipitations on tensile fracture.
\end{abstract}

Keywords: Al-Zn-Mg-Cu alloy; GBF process; EMS process; precipitates

\section{Introduction}

Al-Zn-Mg-Cu cast alloys have been widely used for aeronautical and automotive applications due to their excellent combination castability, mechanical properties, and formability [1-5]. These alloys are mostly fabricated using ingot metallurgy, during which casting defects, such as shrinkage and pores, may develop and deteriorate the mechanical properties of the final product [6-8]. Several approaches are implemented in the aluminum alloy industry to eliminate these casting defects. Among these, gas bubbling filtration (GBF) and electromagnetic stirring (EMS) casting treatments are effective ways to remove casting defects [9-11]. However, these casting treatments can also cause additional effects on the microstructure of the alloy, such as grain refinement and intermetallic phase forming $[5,12,13]$. Therefore, demands for improved mechanical properties necessitate the understanding of these casting treatments on the microstructure of the alloy [14].

Generally, the alloying elements segregate on dendritic grain boundaries during solidification of $\mathrm{Al}-\mathrm{Zn}-\mathrm{Mg}-\mathrm{Cu}$ alloys and form several coarse intermetallics such as T$\left(\mathrm{Al}_{2} \mathrm{Mg}_{3} \mathrm{Zn}_{3}\right)$, S- $\left(\mathrm{Al}_{2} \mathrm{CuMg}\right)$, and Fe-bearing phases. Fine-strengthening precipitate $\mathrm{MgZn}_{2}$ ( $\eta$ phase) forms inside grains during age-hardening treatment. Precipitation evolution during the age-hardening of $\mathrm{Al}-\mathrm{Zn}-\mathrm{Mg}-\mathrm{Cu}$ alloys is in the sequence of SSSS (supersaturated solid solution) $\rightarrow$ GP zone $\rightarrow \eta^{\prime}$ phase $\rightarrow \eta$ phase [15-17]. High strength can be attained by creating a microstructure containing high spatial uniformity of fine precipitates inside grains and a small fraction of coarse precipitates on the grain boundaries [18-27]. 
Many researchers have attempted to improve mechanical properties by optimizing the size and fraction of intragranular and grain boundary precipitates (GBPs) using casting treatment $[28,29]$. For instance, Wannasin et al. [30] reported non-dendritic microstructures refinement by controlling the cooling and gas flow rates. Oh et al. [14] suggested that longer stirring time, from $20 \mathrm{~s}$ to $80 \mathrm{~s}$, during solidification refined the average grain size. Lee et al. [31] also reported effective grain refinement in the microstructure when the degassing time was increased during the GBF process. However, most of the past studies have only focused on the grain refinement effect caused by melt treatments during casting, while the information regarding casting treatment influence on the grain boundary and intragranular precipitates has been neglected. Therefore, a comprehensive analysis is required to observe and optimize grain refinement, as well as to precipitate the size fraction, in cast $\mathrm{Al}-\mathrm{Zn}-\mathrm{Mg}-\mathrm{Cu}$ alloys.

In the present study, we developed $\mathrm{Al}-\mathrm{Zn}-\mathrm{Mg}-\mathrm{Cu}$ alloys using two different melt treatments during casting, i.e., GBF and EMS. The variations in grain refinement and interdendritic precipitate size and distribution were evaluated using microstructural characterization. The tensile properties and strain-hardening behavior of the cast specimens were evaluated under different aging conditions, such as T4 and T6. The results were used to discuss the possibility of improving the mechanical properties of Al- $\mathrm{Zn}-\mathrm{Mg}-\mathrm{Cu}$ alloys by controlling the microstructure using casting treatments.

\section{Experimental Details}

Ten kilograms of alloy melt was produced in an electric resistance furnace. Metals of $99.9 \%$ purity $(\mathrm{Al}, \mathrm{Zn}$, and $\mathrm{Mg}$ ) with two master alloys ( $\mathrm{Al}-5 \mathrm{Zr}$ and $\mathrm{Al}-30 \mathrm{Cu}$ ) were used for melting. The melt was either degassed for $10 \mathrm{~min}$ using Ar gas by the GBF process or electromagnetically stirred for $30 \mathrm{~s}$ or $50 \mathrm{~s}$. A cylindrical mold with a $50 \mathrm{~mm}$ diameter and $200 \mathrm{~mm}$ length was pre-heated to $180^{\circ} \mathrm{C}$, and the $1.5 \mathrm{~kg}$ processed melts were poured into it at $700{ }^{\circ} \mathrm{C}$. The chemical composition of as-cast ingots was measured by inductively coupled plasma optical emission spectrometry (ICP-OES, Oxford instruments, Abingdonon-Thames, UK) as Al-7.0Zn-2.5Mg-1.5Cu-0.2Zr (wt.\%). The GBF-processed specimen is referred to as G-A, while the EMS-processed specimens are referred to as E30-A and E50-A, with respect to stirring time. Samples were solution-treated at $450{ }^{\circ} \mathrm{C}-8 \mathrm{~h}+460{ }^{\circ} \mathrm{C}-8 \mathrm{~h}+$ $470{ }^{\circ} \mathrm{C}-8 \mathrm{~h}$ followed by water quenching. Some of the solution-treated specimens were naturally aged (T4) at $25 \pm 2{ }^{\circ} \mathrm{C}$ for $1000 \mathrm{~h}$, whereas some were artificially peak-aged (T6). T6 was performed immediately after solution treatment at $120^{\circ} \mathrm{C}$ for $24 \mathrm{~h}$.

The specimens for microstructure analysis and mechanical testing were cut from the center of each ingot. The specimens were polished and etched using Keller's etchant $\left(\mathrm{H}_{2} \mathrm{O} 95 \mathrm{ml}+\mathrm{HCl} 2 \mathrm{ml}+\mathrm{HNO}_{3} 2.5 \mathrm{ml}+\mathrm{HF} 1.5 \mathrm{ml}\right)$ for microstructural observation in a scanning electron microscope (SEM) (JSM-7610F, JEOL, Tokyo, Japan). The volume fractions of the secondary phases were measured using an image analyzer. Five SEM images of each sample were used, and the average values are mentioned in Section 3. The chemical composition of secondary phases was determined by an energy dispersive X-ray spectrometer (EDS) (Oxford instruments, Abingdon-on-Thames, UK) attached with the SEM. Electron backscattered diffraction (EBSD) analysis was performed using a low accelerating SEM (JSM7900F, JEOL, Tokyo, Japan). High-resolution transmission electron microscopy (HRTEM) (TF30ST, FEI, OR, USA) was operated at $300 \mathrm{kV}$. Thin foils $(\varnothing=3 \mathrm{~mm}$, thickness $=100 \mu \mathrm{m}$ ) for TEM were prepared by mechanical grinding. The foils were then electro-polished in a jet polisher (TenoPol III, Struers, Ballerup, Denmark) in a 3:1 methanol and $\mathrm{HNO}_{3}$ solution at $-20^{\circ} \mathrm{C}$. The Vickers hardness was measured using a hardness tester (HV-114, Mitutoyo, Tokyo, Japan) with a load of $1 \mathrm{~kg}$ and $15 \mathrm{~s}$ dwell time. The tensile test specimens were prepared with a gauge length of $30 \mathrm{~mm}$ and a diameter of $6 \mathrm{~mm}$. Room temperature tensile tests were conducted using a universal testing machine (8516, Instron, MA, USA) at a strain rate of $10^{-3} \mathrm{~s}^{-1}$. The fractography of tensile-tested specimens was observed and charted via SEM. For hardness and tensile tests, five specimens for each 
condition were tested. The results, exhibiting properties and approach with average points, are reported in the present study.

\section{Results and Discussion}

Figure 1a,b shows the SEM and EBSD micrographs of the representative specimens (G-A, E30-A, E50-A, G-T4, G-T6, E30-T4, and E30-T6). Dendritic cell structures existed in the GBF-processed specimens while globular dendritic structures were observed in the EMS-processed specimens. Globular dendritic structures were formed by partial nucleation and crushing of slurries during solidification [32]. In the as-cast (G-A, E30-A, and E50-A) specimens, secondary phases were located on the interdendritic boundaries consisting of a network morphology. The volume fraction of secondary phases in the G-A specimen was $4.6 \%$, whereas it was $4.8 \%$ and $5.4 \%$ in the E30-A and E50-A specimens, respectively. The equiaxed cell size of the specimens was measured using IPF maps shown in Figure $1 \mathrm{~b}$. The equiaxed cell size of the G-A specimen was $93.8 \mu \mathrm{m}$, and those of the E30-A and E50-A specimens were $82.7 \mu \mathrm{m}$ and $69.3 \mu \mathrm{m}$, respectively, which decreased with increasing stirring time. According to the EBSD inverse pole figure (IPF) and grain boundary analysis of the G-A, E30-A, and E50-A specimens, equiaxed cell boundaries were composed of high-angle grain boundaries (HAGBs). The cell size was the largest $(245 \mu \mathrm{m})$ in the G-A specimen, which also contained many sub-structures. In contrast, the E30-A and E50-A specimens showed a smaller cell size with different grain orientations. Figure 1c shows that the dissolution of the coarse secondary phase located on cell boundaries took place during solution treatment. The volume fraction of secondary phases in the G, E30, and E50 specimens was $0.9 \%, 1.0 \%$, and $2.0 \%$ after $\mathrm{T} 4$, and $1.2 \%, 1.3 \%$, and $2.9 \%$ after $\mathrm{T} 6$, respectively. The decrease in the volume fraction of secondary phases is attributed to the dissolution of $\mathrm{Zn}$ - and $\mathrm{Mg}$-containing particles. These observations are consistent with past studies $[33,34]$. Furthermore, the equiaxed cell size of the as-cast specimens also decreased after the heat treatment, as shown in Figure 1d.

Figure 2 and Table 1 show the EDS elemental mapping analysis of the G- and E30-series specimens in as-cast and heat-treated conditions. Figure $2 \mathrm{a}$, b shows that secondary phases present on the dendritic cell boundaries of the G-A and E30-A specimens are $\mathrm{Al}_{7} \mathrm{Cu}_{2} \mathrm{Fe}$ and $\mathrm{Al}_{2}(\mathrm{ZnMgCu})_{3}$. In $\mathrm{Al}-\mathrm{Zn}-\mathrm{Mg}-\mathrm{Cu}$ alloys, solute atoms tend to segregate on dendritic cell boundaries during solidification and form $\mathrm{Zn}-, \mathrm{Mg}$ - and $\mathrm{Cu}$-rich phases. However, $\mathrm{Cu}$ extends its solubility in the $\mathrm{Zn}-\mathrm{Mg}$-rich intermetallic phase, i.e., the $\mathrm{Al}_{2}(\mathrm{ZnMg})_{3}-\mathrm{T}$ phase, changing its composition to $\mathrm{Al}_{2}(\mathrm{ZnMgCu})_{3}$ [35].

After heat treatment, the $\mathrm{Zn}$ and $\mathrm{Mg}$ elements were readily dissolved in the matrix due to their high diffusion co-efficient, while the $\mathrm{Cu}$ and Fe velocities are low over wide temperature ranges [35]. Subsequently, the network type morphologies of secondary phases in as-cast specimens were changed to the island type. As mentioned previously, the total volume fraction of secondary phases decreased to 1 2\%. Secondary phases were analyzed in G-T4 and E30-T4 specimens and characterized as $\mathrm{Al}_{7} \mathrm{Cu}_{2} \mathrm{Fe}$ phase and $\mathrm{Cu}$ rich remnants, as shown in Figure $2 \mathrm{~b}$,d. It is obvious in Figure $2 \mathrm{a}, \mathrm{b}$ that the continuous interdendritic $\mathrm{Al}_{2}(\mathrm{Zn}, \mathrm{Mg}, \mathrm{Cu})_{3}$ or $\mathrm{Al}_{7} \mathrm{Cu}_{2} \mathrm{Fe}$ precipitates became discontinuous after heat treatment (Figure $2 b, d$ ). These discontinuous precipitates can act as crack initiation sites during the deformation of the alloy, degrading its strength and elongation. The precipitation hardening during T4 tempering occurs at a steady rate, with a lower density of strengthening precipitates and does not lead to higher strength. On the other hand, accelerating precipitation $\left(\eta^{\prime} / \eta\right)$ hardening takes place during $T 6$ treatment, which effectively increases the strength of the alloy. 
(a)
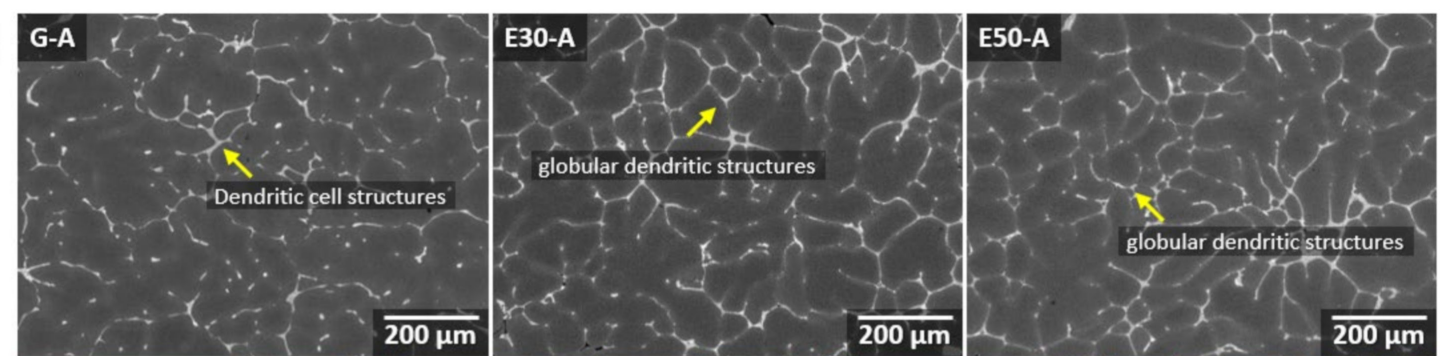

(b)
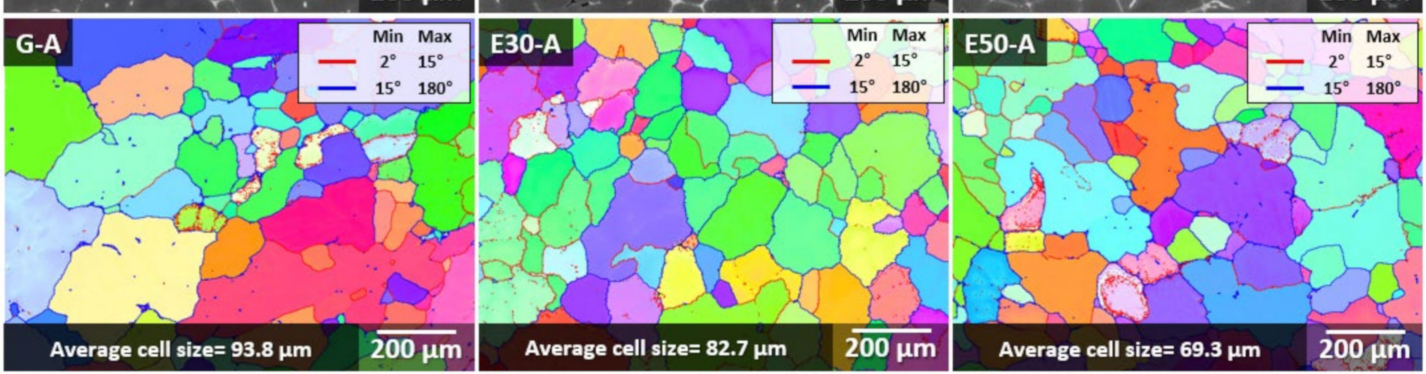

(c)
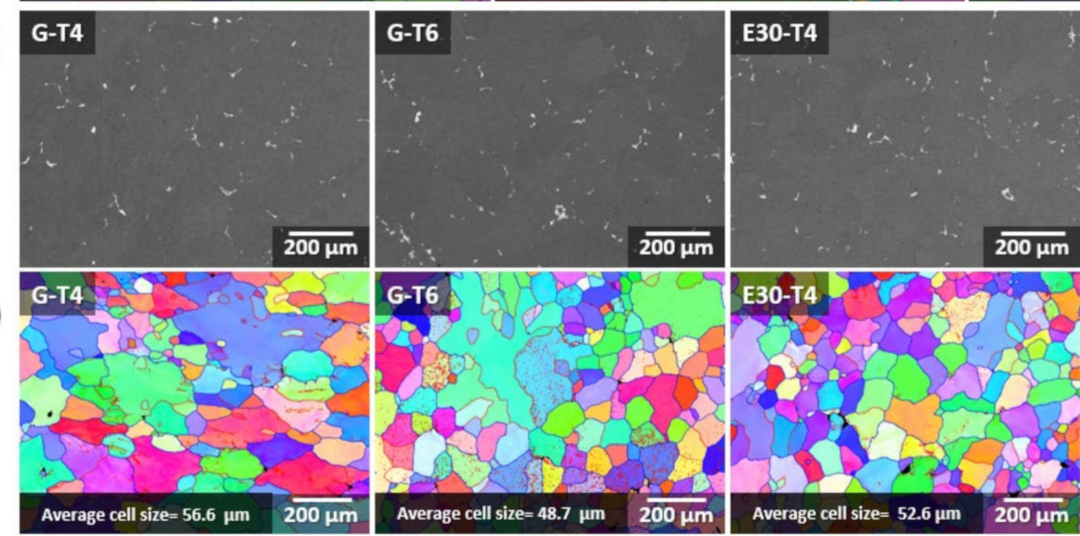

E30-T6

Figure 1. Microstructure analysis of the as-cast and heat-treated specimens showing the solute distribution in $\mathrm{Al}-\mathrm{Zn}-\mathrm{Mg}$ $\mathrm{Cu}$ alloys. (a) SEM micrographs and (b) inverse pole figure (IPF) maps of G-A, E30-A, and E50-A specimens. (c) SEM micrographs and (d) IPF maps of T4 and T6 heat-treated specimens.
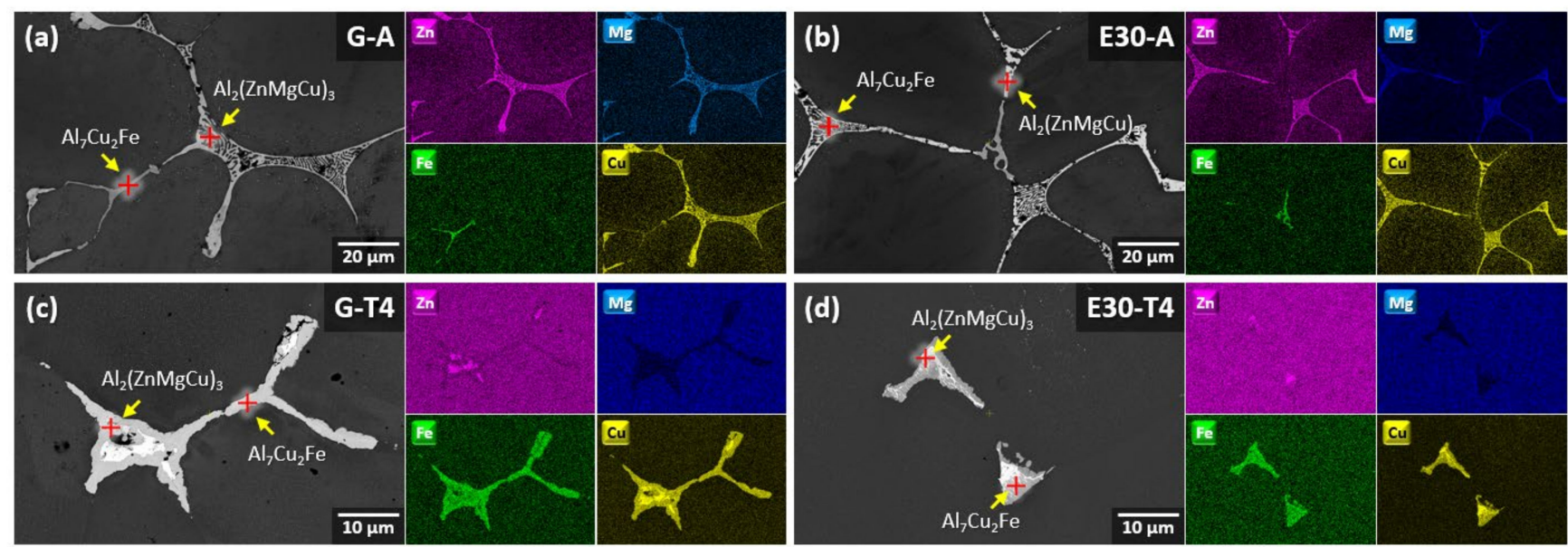

Figure 2. Precipitation analysis of as-cast and heat-treated specimens in $\mathrm{Al}-\mathrm{Zn}-\mathrm{Mg}$-Cu alloys using back-scattered elec-tron (BSE) micrographs and EDS elemental mapping. $\mathrm{Al}_{7} \mathrm{Cu}_{2} \mathrm{Fe}$ and $\mathrm{Al}_{2}(\mathrm{ZnMgCu})_{3}$ phases presented in (a) G-A and (b) E30-A specimens. $\mathrm{Al}_{7} \mathrm{Cu}_{2} \mathrm{Fe}$ phase and $\mathrm{Al}_{2}(\mathrm{ZnMgCu})$ present in (c) G-T4 and (d) E30-T4 specimens. (Red $\mathrm{X}$ sign and yellow arrow are indicating the EDS point analysis of secondary phases presented in Table 1). 
Table 1. EDS point analysis results (wt.\%) of $\mathrm{Al}_{7} \mathrm{Cu}_{2} \mathrm{Fe}$ and $\mathrm{Al}_{2}(\mathrm{ZnMgCu})_{3}$ phases observed in Figure 2.

\begin{tabular}{cccccc}
\hline \multirow{2}{*}{ Elements } & \multicolumn{5}{c}{ Specimens } \\
\cline { 2 - 6 } & G-A & G-T4 & E30-A & E30-T4 & Phase \\
\hline $\mathbf{A l}$ & 58.28 & 47.93 & 57.10 & 49.10 & \\
$\mathbf{M g}$ & 0.49 & 0.07 & 0.29 & 0.04 & \\
$\mathbf{Z n}$ & - & 1.06 & - & 1.43 & $\mathrm{Al}_{7} \mathrm{Cu}_{2} \mathrm{Fe}$ \\
$\mathbf{C u}$ & 8.76 & 35.81 & 9.11 & 36.64 & \\
$\mathbf{F e}$ & 32.48 & 15.13 & 33.50 & 12.79 & \\
\hline $\mathbf{A l}$ & 13.23 & 4.76 & 17.68 & 0.57 & \\
$\mathbf{M g}$ & 18.28 & 0.21 & 12.97 & 0.05 & $\mathrm{Al}_{2}\left(\mathrm{ZnMgCu}_{3}\right.$ \\
$\mathbf{Z n}$ & 37.68 & 12.38 & 38.53 & 9.68 & \\
$\mathbf{C u}$ & 30.81 & 76.85 & 30.82 & 88.86 & \\
$\mathbf{F e}$ & - & 4.76 & - & 0.83 & \\
\hline
\end{tabular}

Figure 3 shows the TEM analysis performed on the E50-T6 specimen confirming fine precipitates presence along $[110]_{\mathrm{Al}}$. Under T4 tempering, only GP zones were formed at room temperature after $1000 \mathrm{~h}$ of natural aging, having a coherent relationship matrix, as shown in Figure 3a. Under T6 tempering, a high density of nano-sized $\eta^{\prime}$ phase was uniformly dispersed in the matrix [22-25,36]. As shown in Figure 3b, the Al matrix and $\eta^{\prime}$ phase have an orientation relationship as $[110]_{\mathrm{Al}} / /[10 \overline{1} 0]_{\eta^{\prime}},(\overline{1} 11)_{\mathrm{Al}} / /(0002)_{\eta^{\prime}}$. The semi-coherent $\eta^{\prime}$ phase is the most effective in obtaining high strength after T6 tempering together in the GPII zone. Figure 3c shows the HR-TEM image and corresponding fast Fourier transform (FFT) of the embedded $\eta$ phase in the Al matrix along $[110]_{\mathrm{Al}}$. The spots of $\eta$ at $1 / 2$ of the (111) matrix reflection can be indexed as $(0002)_{\eta}$, suggesting that the HR-TEM image of the $\eta$ phases is taken along $[10 \overline{1} 0]$. Spots $(0002)_{\eta}$ coincide with the $(\overline{1} 11)_{\mathrm{Al}}$, as do the other spots in the same line.

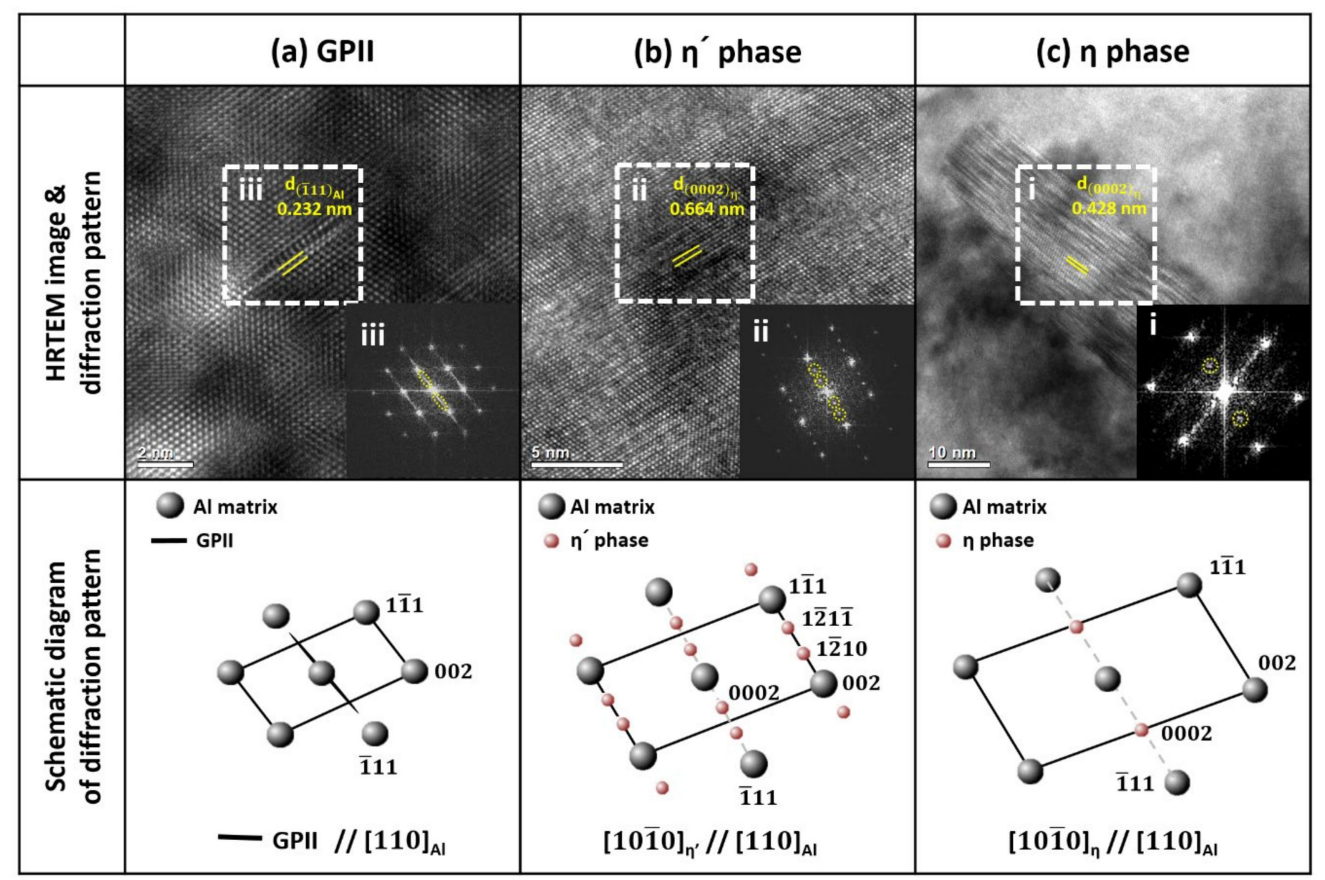

Figure 3. High-resolution TEM images of (a) GPII zones observed in E50-T4 and (b) $\eta^{\prime}$ phase, and (c) $\eta$ phase observed in an E50-T6 specimen.

GP zones usually form during natural aging or at the early stage of artificial aging. GP zones serve as nucleation sites for the formation of metastable $\eta^{\prime}$ phases [34]. The metastable 
$\eta^{\prime}$ phase then transforms into the stable $\eta$ phase $\left(\mathrm{MgZn}_{2}\right)$ which is solely responsible for the peak hardening of $\mathrm{Al}-\mathrm{Zn}-\mathrm{Mg}-\mathrm{Cu}$ alloys [16,22,25-27]. GP zones are categorized into two groups. GPI zones are coherent with the $\mathrm{Al}$ matrix, yielding the internal ordering of $\mathrm{Mg} / \mathrm{Al}$ and $\mathrm{Zn}$ on the (001) matrix, which is dominant during natural aging. GPII zones are Zn-rich layers on a (111) matrix usually nucleated by artificial aging [37-39]. The GPII starts to form from the vacancy-related clusters and is transformed to the $\eta^{\prime}$ phase during after-solution treatment $[40,41]$. The metastable $\eta^{\prime}$ phase is mostly known as the major hardening phase in $\mathrm{Al}-\mathrm{Zn}-\mathrm{Mg}-\mathrm{Cu}$ alloys. Localized strain fields were formed around the finely dispersed $\eta^{\prime}$ phase, which act as barriers for dislocation sliding [42]. The $\eta^{\prime}$ phase has a chemical composition of $\mathrm{Mg}_{2} \mathrm{Zn}_{5-\mathrm{x}} \mathrm{Al}_{2+\mathrm{x}}[24,43]$. Figure $3 \mathrm{~b}$ confirms that $\eta^{\prime}$ has a hexagonal crystal structure and the lattice parameters are $a=0.486 \mathrm{~nm}$ and $c=1.329 \mathrm{~nm}$. $\eta^{\prime}$ transforms into the $\eta\left(\mathrm{MgZn}_{2}\right)$ phase as the aging time increases. Figure $3 \mathrm{c}$ shows that the $\eta$ phase has a hexagonal crystal structure with $\mathrm{a}=0.523 \mathrm{~nm}$ and $\mathrm{c}=0.856 \mathrm{~nm}$.

Table 2 summarizes the Vickers hardness of the G, E30, and E50 specimens under ascast, T4, and T6 conditions. The Vickers hardness value is the highest under the T6 condition while it is the lowest in the as-cast form. The high hardness value of the T6 treated specimen compared to the T4 treated specimen is attributed to effective precipitation hardening during the $\eta^{\prime}$ and $\eta$ phases. When comparing the GBF and EMS processes, it was revealed that the GBF-processed specimen had higher hardness than the EMS-processed specimen. According to microstructure analysis, the volume fraction of the interdendritic precipitates in the GBF-processed specimen was smaller than in the EMS-processed specimen. This lower fraction translated into better precipitation hardening during $\mathrm{T} 6$ tempering resulting in a higher fraction of strengthening precipitates, i.e., higher hardness. The higher hardness value of the E50 specimen is ascribed to its finer grain size, even though it had a higher fraction of interdendritic precipitates.

Table 2. Vickers hardness of GBF- and EMS-processed specimens of as-cast, T4, and T6 heat treatment conditions.

\begin{tabular}{cccc}
\hline \multirow{2}{*}{ Specimens } & \multicolumn{3}{c}{ Vickers Hardness (Hv) } \\
\cline { 2 - 4 } & A & T4 & T6 \\
\hline G & $142 \pm 1.4$ & $169 \pm 1.7$ & $182 \pm 1.8$ \\
E30 & $125 \pm 1.2$ & $161 \pm 1.6$ & $174 \pm 1.7$ \\
E50 & $137 \pm 1.4$ & $165 \pm 1.6$ & $183 \pm 1.8$ \\
\hline
\end{tabular}

Figure 4 and Table 3 show the tensile test results of the $G$ and $E$ specimens under ascast T6 and T4 conditions. The tensile properties of the GBF specimens were better than the EMS specimens under as-cast and heat-treated conditions. The better mechanical behavior of the GBF-processed specimens is attributed to their lower fraction of interdendritic precipitates, which act as crack nucleation sites during tensile deformation. Similarly, a lower fraction of interdendritic precipitates reflected better tensile properties in the E30 specimen compared to the E50 specimen. The average tensile strength values of the $G$, E30, and E50 specimens were approximately $492 \mathrm{MPa}, 489 \mathrm{MPa}$, and $440 \mathrm{MPa}$, respectively. Compared to the $\mathrm{T} 4$ tempered specimens, the $\mathrm{T} 6$ tempered specimens had a much higher tensile strength. The average tensile strength values of the G, E30, and E50 specimens were approximately $545 \mathrm{MPa}, 530 \mathrm{MPa}$, and $521 \mathrm{MPa}$, respectively. The higher strength of the T6 specimen is attributed to a large fraction of strengthening precipitates formed during artificial aging, as shown in the TEM images in Figure 3b,c. In contrast, all the specimens showed better elongation under T4 conditions than T6. This can be explained by the TEM image analysis of the T4 specimen in Figure 3a showing only nanosized GPII zones. It is well known that dislocations shear these nanosized clusters during plastic deformation. This shearing can effectively impede the dislocation motion, resulting in higher elongation. The effectiveness of nanosized GP zone shearing is further highlighted by strain-hardening curves in the Figure $4 a, b$ insets. The strain-hardening rate in all specimens under the T4 
condition is better than under the T6 condition, which is attributed to GP zone shearing by dislocations. Moreover, the strain-hardening behavior of the T6 specimen is lower than for the T4 specimen in all conditions displayed by the strain-hardening curve in Figure $4 \mathrm{~b}$. The precipitation sequence in an $\mathrm{Al}-\mathrm{Zn}-\mathrm{Mg}$-Cu alloy usually begins with the formation of $\mathrm{Mg}$ - and $\mathrm{Zn}$-rich clusters during natural aging at room temperature, or at an early stage of artificial aging. These clusters transform into coherent GP zones, followed by a semi-coherent $\eta^{\prime}$ phase, and finally, an incoherent $\eta$ phase, with time and temperature. Therefore, a peak-aged alloy is mostly comprised of $\eta^{\prime}$ and $\eta$ precipitates, while only GP zones form during natural aging (T4). Each precipitate imparts varying effects to the tensile behavior of the alloy based on their interplay with dislocation during plastic deformation.
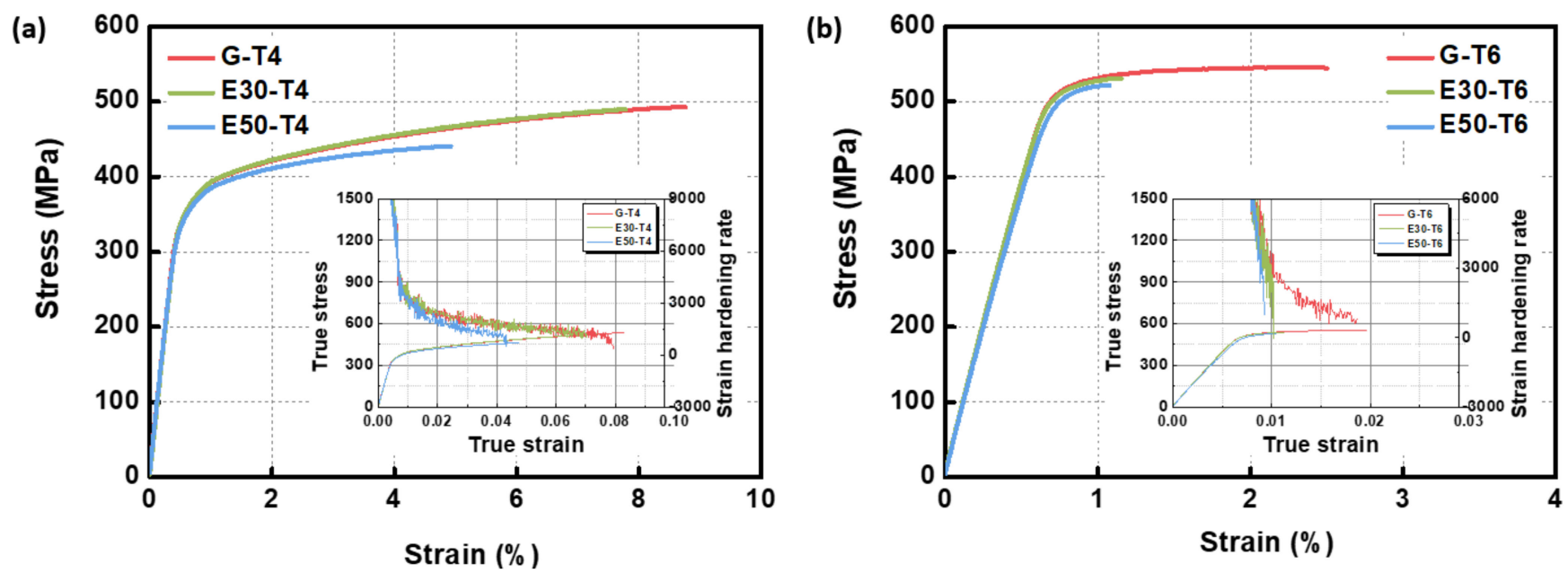

Figure 4. Engineering and true stress-strain and strain-hardening rate curves of the (a) G-T4, E30-T4, and E50-T4 specimens and (b) G-T6, E30-T6, and E50-T6 specimens.

Table 3. Tensile properties of GBF- and EMS-processed specimens of as-cast, T4, and T6 heat treatment conditions.

\begin{tabular}{ccccc}
\hline Heat Treatment & Specimen & Yield Strength (MPa) & Tensile Strength (MPa) & Elongation (\%) \\
\hline \multirow{2}{*}{ T4 } & G & $370 \pm 4.4$ & $492 \pm 5.9$ & $8.1 \pm 0.10$ \\
& E30 & $372 \pm 4.5$ & $489 \pm 5.8$ & $7.5 \pm 0.05$ \\
& E50 & $359 \pm 4.3$ & $440 \pm 5.3$ & $4.4 \pm 0.05$ \\
\hline \multirow{2}{*}{ T6 } & G & $526 \pm 6.3$ & $545 \pm 6.5$ & $1.8 \pm 0.02$ \\
& E30 & $521 \pm 6.2$ & $530 \pm 6.4$ & $0.5 \pm 0.01$ \\
& E50 & $516 \pm 6.2$ & $521 \pm 6.3$ & $0.4 \pm 0.01$ \\
\hline
\end{tabular}

According to precipitation strengthening theory, dislocations move forward by shearing precipitates $[27,44,45]$. In the shearing mechanism, the coherency strengthening $\left(\Delta \sigma_{c s}\right)$ contributes to the yield strength; $\Delta \sigma_{\mathcal{~ S}}$ is expressed as the following: $[46,47]$

$$
\Delta \sigma_{\mathcal{C S}}=M \alpha_{\varepsilon}\left(G \varepsilon_{\mathcal{c}}\right)^{\frac{3}{2}}\left(\frac{r f}{0.5 G b}\right)
$$

where $M$ is the mean orientation factor (3.06 for fcc metals), $\alpha_{\varepsilon}=2.6$ for face-centered cubic (fcc) metals, $G$ is the shear modulus ( $26.9 \mathrm{GPa}$ for the $\mathrm{Al} 7075$ alloy), $\varepsilon_{\mathcal{C}}$ is the constrained lattice parameter misfit, $r$ is the radius of the precipitates, and $f$ is the volume fraction of the precipitates. According to TEM analysis, the average diameter of the GPII zones was $\sim 2.3 \mathrm{~nm}$ and that of the $\eta^{\prime}$ phase was $\sim 6.6 \mathrm{~nm}$; thus, they acted to increase the strengthening of the T4 and T6 specimens by shearing mechanisms, while the $\eta$ phase, with a size of $\sim 20 \mathrm{~nm}$, had difficulty enhancing strength. Therefore, the T4 specimen showed lower tensile strength compared to the T6 specimen due to the high volume of fracturing in 
the $\eta$ phase. This observation confirms that $\eta$ phases are not effective for the dislocation shearing mechanism.

Furthermore, the strain-hardening behavior of the GBF-processed specimen was better than for both the EMS-processed specimens. As observed in the microstructure analysis, the volume fraction of coarse interdendritic precipitates in the EMS-processed specimen was higher than in the GBF-processed samples. The coarse interdendritic precipitates induced strain localization in their surroundings, resulting in crack initiation during plastic deformation, and alloy fractures with low elongation. Despite the presence of fine intergranular precipitates, a lower volume fraction of coarse precipitates is also significant for the strain-hardening behavior of the Al- $\mathrm{Zn}-\mathrm{Mg}$-Cu alloys.

According to the fractographic observation in Figure 5, all the specimens showed intergranular/interdendritic fractures. Porosities were not observed in the GBF-processed specimen, but small pores existed in the EMS-processed specimens due to severe EMS treatment. Stress was localized in the vicinity of pores leading to a decrease in tensile elongation. The grain size of the EMS-processed specimens was smaller than that of the GBF-processed specimens, as confirmed in Figure 1. The brittle fractures in the T4 and $\mathrm{T} 6$ treated specimens were associated with the continuous $\eta^{\prime}$ phases combined with intergranular/interdendritic cracking. Primary precipitates along grain boundaries grow and aggregate to become coarse intergranular phases during the heat treatment process. Thus, the present study demonstrated that the lower volume fraction of coarse secondary phases in GBF-processed specimens showed better elongation. A lower volume fraction of the coarse particles not only decreases the stress localization during plastic deformation but also the intergranular/interdendritic cracking.
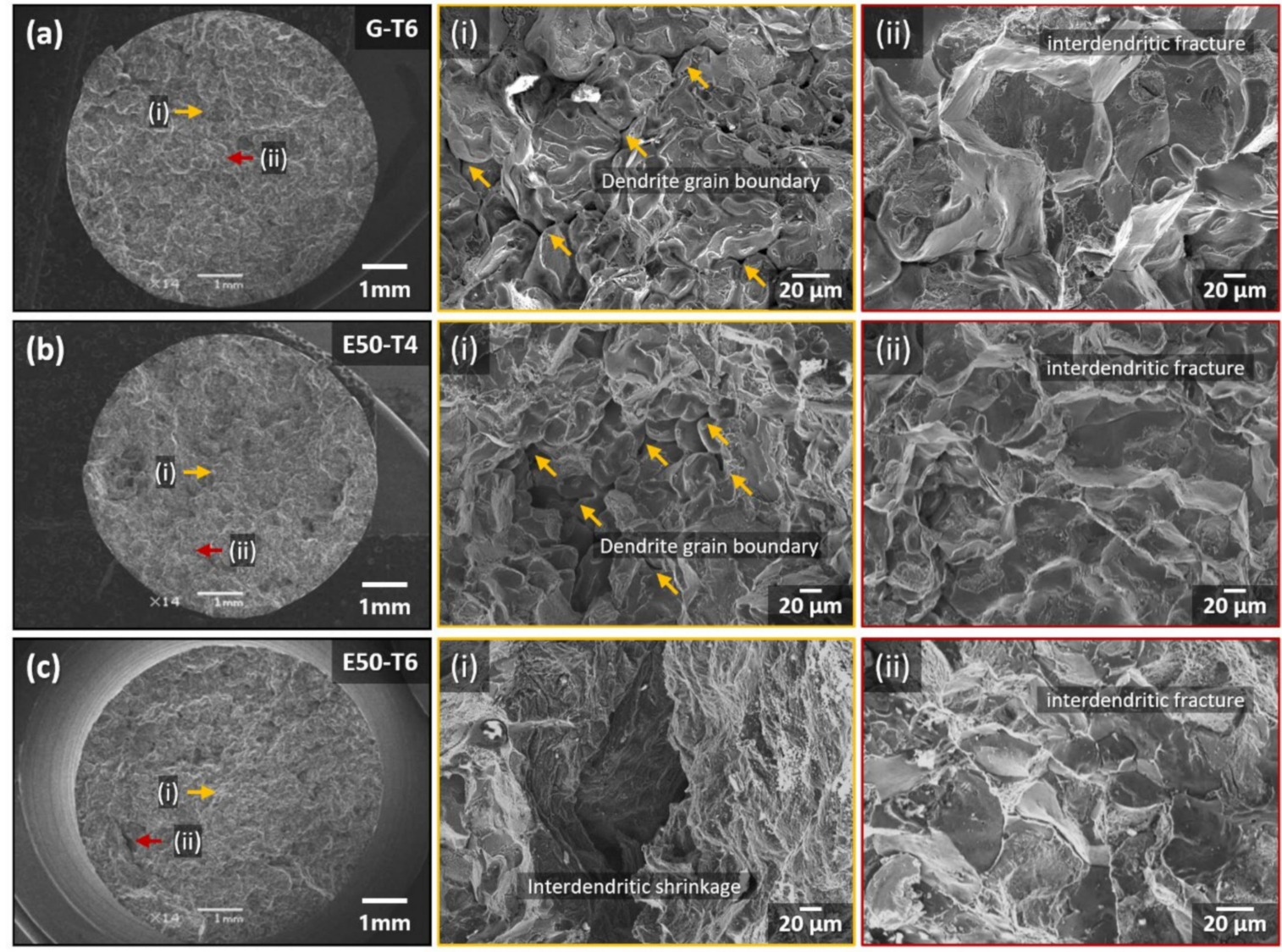

Figure 5. Fractography of the tensile tested (a) G-T6, (b) E50-T4, and (c) E50-T6 specimens. Yellow arrows indicate the intergranular/interdendritic fracture. 


\section{Conclusions}

In this study, the effects of casting methods (GBF and EMS) and heat treatments (T4 and $\mathrm{T} 6$ ) on the tensile properties of $\mathrm{Al}-\mathrm{Zn}-\mathrm{Mg}$-Cu alloys were investigated. The grain size was reduced by a newly proposed EMS process compared to the conventional GBF method. The T6 tempered specimen had relatively higher strength and lower elongation than the $\mathrm{T} 4$ tempered specimen due to the presence of coherent and semi-coherent phases, such as the GPII and $\eta^{\prime}$ phase. Grain refinement is essential to enhance the tensile strength of all the metals including the $\mathrm{Al}-\mathrm{Zn}-\mathrm{Mg}-\mathrm{Cu}$ alloy. A network structure of grain boundary precipitates, in $\mathrm{S}\left(\mathrm{Al}_{2} \mathrm{CuMg}\right)$ or $\mathrm{Al}_{7} \mathrm{Cu}_{2} \mathrm{Fe}$ phases, link together to create crack propagation during tensile deformation, leading to the premature failure of an $\mathrm{Al}-\mathrm{Zn}-\mathrm{Mg}-\mathrm{Cu}$ alloy. The formation of grain boundary precipitates should be controlled to reduce the possible crack initiation sites.

Author Contributions: Conceptualization, S.P., J.G.K. and H.S.; methodology, S.P. and S.H.K.; software, S.P. and S.H.K.; validation, K.E. and J.B.S.; formal analysis, S.P.; investigation, S.P. and H.K.; resources, K.E.; data curation, S.P. and H.K.; writing—original draft preparation, S.P., S.H.K., J.G.K. and H.S.; writing — review and editing, N.S.R., I.D.J., K.E., and J.B.S.; visualization, J.G.K. and H.S.; supervision, J.G.K. and H.S.; project administration, J.G.K. and H.S.; funding acquisition, J.G.K. and H.S. All authors have read and agreed to the published version of the manuscript.

Funding: This work was supported by the National Research Foundation of Korea (NRF) grant funded by the Korean Government (MSIT) (No. NRF-2020R1C1C1006214), the Ministry of Trade, Industry and Energy (MOTIE, Korea) under the Industrial Technology Innovation Program (Grant No. 20010502), and the Technology Innovation Program (20011186) funded by the Ministry of Trade, Industry \& Energy (MOTIE).

Data Availability Statement: The raw/processed data required to reproduce these findings cannot be shared at this time, as the data also form part of an ongoing study.

Conflicts of Interest: The authors declare no conflict of interest.

\section{References}

1. Liu, C.; Feng, Z.; Ma, P.; Zhou, Y.; Li, G.; Zhan, L. Reversion of Natural Ageing and Restoration of Quick Bake-Hardening Response in Al-Zn-Mg-Cu Alloy. J. Mater. Sci. Technol. 2021, 95, 88-94. [CrossRef]

2. Omer, K.; Abolhasani, A.; Kim, S.; Nikdejad, T.; Butcher, C.; Wells, M.; Esmaeili, S.; Worswick, M. Process Parameters for Hot Stamping of AA7075 and D-7xxx to Achieve High Performance Aged Products. J. Mater. Process. Technol. 2018, 257, 170-179. [CrossRef]

3. Yu, M.; Zhang, Y.; Li, X.; Wen, K.; Xiong, B.; Li, Z.; Yan, L.; Yan, H.; Liu, H.; Li, Y. Effect of Recrystallization on Plasticity, Fracture Toughness and Stress Corrosion Cracking of a High-Alloying Al-Zn-Mg-Cu Alloy. Mater. Lett. 2020, 275, 128074. [CrossRef]

4. Zhang, Z.; Chen, K.; Fang, H.; Qi, X.; Liu, G. Effect of Yb Addition on Strength and Fracture Toughness of Al-Zn-Mg-Cu-Zr Aluminum Alloy. Trans. Nonferr. Met. Soc. China 2008, 18, 1037-1042. [CrossRef]

5. Bai, P.; Hou, X.; Zhang, X.; Zhao, C.; Xing, Y. Microstructure and Mechanical Properties of a Large Billet of Spray Formed Al-Zn-Mg-Cu Alloy with High Zn Content. Mater. Sci. Eng. A 2009, 508, 23-27. [CrossRef]

6. Xu, C.; Zhao, J.; Guo, A.; Li, H.; Dai, G.; Zhang, X. Effects of Injection Velocity on Microstructure, Porosity and Mechanical Properties of a Rheo-Diecast Al-Zn-Mg-Cu Aluminum Alloy. J. Mater. Process. Technol. 2017, 249, 167-171. [CrossRef]

7. Fan, C.H.; Chen, Z.H.; He, W.Q.; Chen, J.H.; Chen, D. Effects of the Casting Temperature on Microstructure and Mechanical Properties of the Squeeze-Cast Al-Zn-Mg-Cu Alloy. J. Alloys Compd. 2010, 504, L42-L45. [CrossRef]

8. Koutiri, I.; Bellett, D.; Morel, F.; Augustins, L.; Adrien, J. High Cycle Fatigue Damage Mechanisms in Cast Aluminium Subject to Complex Loads. Int. J. Fatigue 2013, 47, 44-57. [CrossRef]

9. Qiu, Y.; Zhang, Z.; Luo, Y.; Gao, M.; Li, B.; Chen, C. Effect of Coupled Annular Electromagnetic Stirring and Intercooling on the Microstructures, Macrosegregation and Properties of Large-Sized 2219 Aluminum Alloy Billets. Int. J. Mater. Res. 2018, 109, 469-475. [CrossRef]

10. Mapelli, C.; Gruttadauria, A.; Peroni, M. Application of Electromagnetic Stirring for the Homogenization of Aluminium Billet Cast in a Semi-Continuous Machine. J. Mater. Process. Technol. 2010, 210, 306-314. [CrossRef]

11. Guo, S.; Le, Q.; Zhao, Z.; Han, Y.; Cui, J. Effect of a Low Frequency Electromagnetic Field on the Direct-Chill (DC) Casting of AZ80 Magnesium Alloy Ingots. Int. J. Mater. Res. 2006, 97, 1539-1544. [CrossRef]

12. Ghiaasiaan, R.; Amirkhiz, B.S.; Shankar, S. Quantitative Metallography of Precipitating and Secondary Phases after Strengthening Treatment of Net Shaped Casting of Al-Zn-Mg-Cu (7000) Alloys. Mater. Sci. Eng. A 2017, 698, 206-217. [CrossRef] 
13. Rana, R.S.; Purohit, R.; Das, S. Reviews on the Influences of Alloying Elements on the Microstructure and Mechanical Properties of Aluminum Alloys and Aluminum Alloy Composites. Int. J. Sci. Res. Publ. 2012, 2, 1-8.

14. Oh, S.W.; Bae, J.W.; Kang, C.G. Effect of Electromagnetic Stirring Conditions on Grain Size Characteristic of Wrought Aluminum for Rheo-Forging. J. Mater. Eng. Perform. 2008, 17, 57-63. [CrossRef]

15. Degischer, H.P.; Lacom, W.; Zahra, A.; Zahra, C.Y. Decomposition Processes in an Al-5\% Zn-1\% Mg Alloy. Int. J. Mater. Res. 1980, 71, 231-238. [CrossRef]

16. Yang, W.; Ji, S.; Zhang, Q.; Wang, M. Investigation of Mechanical and Corrosion Properties of an Al-Zn-Mg-Cu Alloy under Various Ageing Conditions and Interface Analysis of $\mathrm{H}^{\prime}$ Precipitate. Mater. Des. 2015, 85, 752-761. [CrossRef]

17. Marlaud, T.; Deschamps, A.; Bley, F.; Lefebvre, W.; Baroux, B. Influence of Alloy Composition and Heat Treatment on Precipitate Composition in Al-Zn-Mg-Cu Alloys. Acta Mater. 2010, 58, 248-260. [CrossRef]

18. Xu, X.; Zheng, J.; Li, Z.; Luo, R.; Chen, B. Precipitation in an Al-Zn-Mg-Cu Alloy during Isothermal Aging: Atomic-Scale HAADF-STEM Investigation. Mater. Sci. Eng. A 2017, 691, 60-70. [CrossRef]

19. Liu, S.; Li, Q.; Lin, H.; Sun, L.; Long, T.; Ye, L.; Deng, Y. Effect of Quench-Induced Precipitation on Microstructure and Mechanical Properties of 7085 Aluminum Alloy. Mater. Des. 2017, 132, 119-128. [CrossRef]

20. Dai, P.; Luo, X.; Yang, Y.; Kou, Z.; Huang, B.; Zang, J.; Ru, J. High Temperature Tensile Properties, Fracture Behaviors and Nanoscale Precipitate Variation of an Al-Zn-Mg-Cu Alloy. Prog. Nat. Sci. 2020, 30, 63-73. [CrossRef]

21. Lervik, A.; Marioara, C.D.; Kadanik, M.; Walmsley, J.C.; Milkereit, B.; Holmestad, R. Precipitation in an Extruded AA7003 Aluminium Alloy: Observations of 6xxx-Type Hardening Phases. Mater. Des. 2020, 186, 108204. [CrossRef]

22. Guo, W.; Guo, J.; Wang, J.; Yang, M.; Li, H.; Wen, X.; Zhang, J. Evolution of Precipitate Microstructure during Stress Aging of an Al-Zn-Mg-Cu Alloy. Mater. Sci. Eng. A 2015, 634, 167-175. [CrossRef]

23. Kverneland, A.; Hansen, V.; Thorkildsen, G.; Larsen, H.B.; Pattison, P.; Li, X.Z.; Gjønnes, J. Transformations and Structures in the Al-Zn-Mg Alloy System: A Diffraction Study Using Synchrotron Radiation and Electron Precession. Mater. Sci. Eng. A 2011, 528, 880-887. [CrossRef]

24. Chung, T.-F.; Yang, Y.-L.; Huang, B.-M.; Shi, Z.; Lin, J.; Ohmura, T.; Yang, J.-R. Transmission Electron Microscopy Investigation of Separated Nucleation and In-Situ Nucleation in AA7050 Aluminium Alloy. Acta Mater. 2018, 149, 377-387. [CrossRef]

25. Ibrahim, M.F.; Samuel, A.M.; Samuel, F.H. A Preliminary Study on Optimizing the Heat Treatment of High Strength Al-Cu-MgZn Alloys. Mater. Des. 2014, 57, 342-350. [CrossRef]

26. Zhan, L.; Lin, J.; Dean, T.A.; Huang, M. Experimental Studies and Constitutive Modelling of the Hardening of Aluminium Alloy 7055 under Creep Age Forming Conditions. Int. J. Mech. Sci. 2011, 53, 595-605. [CrossRef]

27. Wen, K.; Fan, Y.; Wang, G.; Jin, L.; Li, X.; Li, Z.; Zhang, Y.; Xiong, B. Aging Behavior and Precipitate Characterization of a High Zn-Containing Al-Zn-Mg-Cu Alloy with Various Tempers. Mater. Des. 2016, 101, 16-23. [CrossRef]

28. Yang, C.; Zhao, Q.; Zhang, Z.; Li, L.; Tian, W.; Liu, R.; Zhang, P.; Xu, Y.; Li, Y.; Zhang, Z.; et al. Nanoparticle Additions Promote Outstanding Fracture Toughness and Fatigue Strength in a Cast Al-Cu Alloy. Mater. Des. 2020, 186, 108221. [CrossRef]

29. Paidar, M.; Tahani, K.; Vaira Vignesh, R.; Ojo, O.O.; Ezatpour, H.R.; Moharrami, A. Modified Friction Stir Clinching of 2024-T3 to 6061-T6 Aluminium Alloy: Effect of Dwell Time and Precipitation-Hardening Heat Treatment. Mater. Sci. Eng. A 2020, 791, 139734. [CrossRef]

30. Wannasin, J.; Martinez, R.A.; Flemings, M.C. Grain Refinement of an Aluminum Alloy by Introducing Gas Bubbles during Solidification. Scr. Mater. 2006, 55, 115-118. [CrossRef]

31. Lee, C.; So, T.; Shin, K. Effect of Gas Bubbling Filtration Treatment on Microporosity Variation in A356 Aluminium Alloy. Acta Metall. Sin. (Engl. Lett.) 2016, 29, 638-646. [CrossRef]

32. Yang, Z.; Kang, C.G.; Seo, P.K. Evolution of the Rheocasting Structure of A356 Alloy Investigated by Large-Scale Crystal Orientation Observation. Scr. Mater. 2005, 52, 283-288. [CrossRef]

33. Safyari, M.; Moshtaghi, M.; Kuramoto, S. on the role of traps in the microstructural control of environmental hydrogen embrittlement of a 7xxx series aluminum alloy. J. Alloys Compd. 2021, 855, 157300. [CrossRef]

34. Kayani, S.H.; Jung, J.G.; Kim, M.S.; Kwangjun, E. Effect of cooling rate on precipitation behavior of Al-7.65Zn-2.59Mg-1.95Cu alloy with minor elements of $\mathrm{Zr}$ and Ti. Met. Mat. Int. 2020, 26, 1079-1086. [CrossRef]

35. Robson, J.D. Microstructural evolution in aluminum alloy 7050 during processing. Mater. Sci. Eng. A 2004, 382, $112-121$. [CrossRef]

36. Tang, L.; Zhang, H.; Guo, Q.; Liu, C.; Li, C.; Liu, Y. The Precipitation of $\eta$ Phase during the Solution Treatments of Allvac 718Plus Mater. Charact. 2021, 176, 111142. [CrossRef]

37. Guinier, A. Structure of Age-Hardened Aluminium-Copper Alloys. Nature 1938, 142, 569-570. [CrossRef]

38. Preston, G.D. The Diffraction of X-Rays by Age-Hardening Aluminium Copper Alloys. Proc. R. Soc. Lond. A 1938, 167, 526-538. [CrossRef]

39. Rioja, R.J.; LAughlin, D.E. The Early Stages of GP Zone Formation in Naturally Aged Ai-4 Wt Pct Cu Alloys. Metall. Mater. Trans. A 1977, 8, 1257-1261. [CrossRef]

40. Nicholson, R.B.; Nutting, J. Direct Observation of the Strain Field Produced by Coherent Precipitated Particles in an Age-Hardened Alloy. J. Theor. Appl. Phys. 2006, 3, 531-535. [CrossRef] 
41. Chang, Y.-C. Crystal Structure and Nucleation Behavior of (111) Precipitates in an Aluminum-3.9copper-0.5magnesium-0.5silver (Wt. Percent) Alloy. Ph.D. Thesis, Carnegie Mellon University, Pittsburgh, PA, USA, 1992. Available online: https://www. proquest.com/docview/303989724?pq-origsite=gscholar\&fromopenview=true (accessed on 15 July 2021).

42. Ning, Z.L.; Guo, S.; Zhang, M.X.; Cao, F.Y.; Jia, Y.D.; Sun, J.F. Characterization of the Secondary Phases in Spray Formed Al-Zn-Mg-Cu-Sc-Zr Alloy during Hot Compression. J. Mater. Res. 2016, 31, 2465-2472. [CrossRef]

43. Chung, T.-F.; Yo-Lun, Y.; Hsiao, C.-N.; Li, W.-C.; Huang, B.-M.; Tsao, C.-S.; Shi, Z.; Lin, J.; Fischione, P.; Ohmura, T.; et al. Morphological Evolution of GP Zones and Nanometer-Sized Precipitates in the AA2050 Aluminium Alloy. Int. J. Lightweight Mater. Manuf. 2018, 1, 142-156. [CrossRef]

44. Yong, Q.L. Secondary Phases in Steels; Press of Metallurgy Industry: Beijing, China, 2006.

45. Li, Z.; Chai, F.; Yang, L.; Luo, X.; Yang, C. Mechanical Properties and Nanoparticles Precipitation Behavior of Multi-Component Ultra High Strength Steel. Mater. Des. 2020, 191, 108637. [CrossRef]

46. Ma, K.; Wen, H.; Hu, T.; Topping, T.D.; Isheim, D.; Seidman, D.N.; Lavernia, E.J.; Schoenung, J.M. Mechanical Behavior and Strengthening Mechanisms in Ultrafine Grain Precipitation-Strengthened Aluminum Alloy. Acta Mater. 2014, 62, 141-155. [CrossRef]

47. Ghiaasiaan, R.; Shankar, S. Structure-Property Models in Al-Zn-Mg-Cu Alloys: A Critical Experimental Assessment of Shape Castings. Mater. Sci. Eng. A 2018, 733, 235-245. [CrossRef] 